\title{
An Investigation of Women Engineers in Non- Traditional Occupations in the Thai Construction Industry
}

Nuanthip Kaewsri, (Department of Civil Engineering, Chulalongkorn University, Thailand)

Tanit Tongthong, (Department of Civil Engineering, Chulalongkorn University, Thailand)

\begin{abstract}
For over a decade, the public and the private sectors have carried out research aimed at attracting women engineers to the construction industry and retaining them. However, studies of women engineers working in other types of construction-related businesses apart from contractor companies such as consultancies, developers, etc., are scarce. This paper aims to examine the experiences of women engineers in non-traditional careers and the implications for their employment turnover. A literature search of women's careers in construction was undertaken in conjunction with semi-structured interviews with a sampling of 141 individuals. Results from three viewpoints, viz those of professional men and women engineers in contractor companies, and of women engineers in non-contractor companies, were found to differ in many respects, including their viewpoints about career advancement, career path and the difficulties involved. It was also found that women engineers in contractor companies were much more affected by problems such as sexual harassment, work-life conflicts and equal opportunity than women engineers in non-contractor companies. Turnover rates of women engineers and their reasons for leaving were examined. Women engineers, particularly those in contractor companies, had to confront more barriers in non-traditional careers than their male counterparts. Nonetheless, working in non-contractor companies provides a viable alternative for women engineers who want to have successful careers in the Thai construction industry.
\end{abstract}

Keyword: Civil engineer; Women in construction; Non-Traditional career; Thailand

\section{Introduction}

There are several factors which determine whether a project will succeed or fail in the Thai construction industry. Staffing is a critical aspect with a varying spectrum of personnel ranging from executives, project managers, project engineers, operating engineers, employees at different levels and workers. The action of each individual who is involved in a project affects the overall outcome of the project (Schneider, 1976). Engineers, particularly civil engineers, play a vital role in construction projects. Before a project can be commissioned, engineers have to study and assess the project's feasibility. After a project is approved, they plan, design and supervise every stage of construction. Starting their work even before a project takes off, civil engineers coordinate with the project owners, project advisors, main contractors, subcontractors, and even material suppliers to ensure that the project goals are achieved. The construction industry has essentially two important components, namely productive and supportive work. A construction project cannot be successful with just one component. Likewise, civil engineering also comprises productive and supportive work (Lingard and Lin, 2004). There are high levels of managerial and administrative responsibility (Parmly, 2003). Managers or 
organizations owning the project should pay close attention to the performance of engineering groups because it is an integral part of a successful project (Angus et al., 2000).

The nature of construction fieldwork and organizational structure as well as the culture of the industry give rise to a large number of obstacles to engineers and, in particular, for women engineers, whose status has been obscure (Dainty and Lingard, 2006). In such a maledominant environment, women engineers are easily neglected by construction managers or organizations. It is widely acknowledged that construction is one of the industries where professional women are under-represented (Dainty et al., 2000a, b; Fielden et al., 2000, Gale, 1994). A lack of information from the perspectives of both men and women engineers and inadequate separate studies of men engineers and women engineers lead to ill-informed judgments about the latter's managerial skills in many developing countries, Thailand being no exception.

\section{Female Graduates in Civil Engineering and Women in the Thai Construction Industry}

As a developing country, Thailand needs a large pool of civil engineers to help expand its infrastructure. Unfortunately, only a small number of civil engineers graduate each year. The Thailand Research Fund reported that women accounted for $12.3 \%$ of the Thai civil engineer workforce in 2008, a 43.5\% increase from 1999. Data from Thailand Council of Engineers (see Table 1) showed that out of 50,670 civil engineers holding licences for professional engineering practices, the promotion rate of women civil engineers from associate engineers to chartered engineers was $0.3 \%$, while the promotion rate of men civil engineers from associate engineers to chartered engineers was $3.2 \%$, ten times that of their female counterpart.. It was also shown that the promotion rate of women civil engineers from associate engineers to fellow engineers was $4.4 \%$, while the promotion rate among men civil engineers from associate engineers to fellow engineers was $15.4 \%$. Hence it is obvious that the chances of promotion were relatively slimmer for women engineers.

\begin{tabular}{|l|r|r|r|r|}
\hline \multirow{2}{*}{\multicolumn{1}{c}{$\begin{array}{c}\text { Classification of } \\
\text { Civil Engineers }\end{array}$}} & \multicolumn{2}{|c|}{ Male } & \multicolumn{2}{c|}{ Female } \\
\cline { 2 - 5 } & Number & Per cent & Number & Per cent \\
\hline Associate Engineers & 39,094 & 81.4 & 2,528 & 95.3 \\
\hline Fellow Engineers & 7,369 & 15.4 & 115 & 4.4 \\
\hline Chartered Engineers & 1,555 & 3.2 & 9 & 0.3 \\
\hline \multicolumn{1}{|c|}{ Total } & 48,018 & 100.0 & 2,652 & 100.0 \\
\hline
\end{tabular}

Table 1 Classification of civil engineers with registered engineering licences

\section{Engineering as a Career for Women in the Construction Industry}

Most previous researches of women in construction industry have focused on women working in contractor company and how to boost the participation of women in the construction workplace, the objective being to help solve the labour crisis and skill shortage (Agapiou, 2002) rather than to improve equality of opportunity (Amaratunga et al., 2005). There have been few studies on the obstacles hindering women's entry into the construction industry, the problems of career development for women engineers in the construction industry, the challenges faced by women taking up non-traditional careers in the construction industry, and guidelines for solving such problems. The details are as follow: 


\section{Obstacles to Women's Entry into the Construction Industry}

Research has been conducted on obstacles preventing women from entering this career path by (Fielden et al., 2000; Amaratunga et al., 2005). Findings have indicated that women are reluctant to choose this career for several reasons, including the poor image of the industry, a lack of information and knowledge of this career, male-centric criteria, recruiting procedures and methods, sexually discriminatory attitudes, male-dominated culture, and a hostile working environment. Besides, women do not have role models or mentors to coach and train them (Khazanet, 1996; Yates, 2001). Furthermore, a study in Singapore identified obstacles preventing women undergraduates from entering the construction industry upon graduation. These obstacles were both external and internal factors (Ling and Poh, 2004). It was not easy for women to gain access to the industry because of sexual discrimination against them, the harsh work environment of construction sites, lack of adequate knowledge about the industry and an insufficient number of successful women engineers to act as role models. There was also evidence of discrimination and sexual harassment. All these factors had a negative impact on the career options of South African women in the construction industry (Madikizela and Haupt, 2010).

\section{Problems of Career Development for Women in the Construction Industry}

In a study, Gale (1994) investigated why there were a relatively small number of women professionals at management level. When career advancement of women engineers was compared to that of men engineers, it was found that women engineers tended to stagnate in their organizational hierarchies (Dainty et al., 2000a, b). In 1999, Bennett et al., found that professional women already working in the industry had higher expectations and had more commitment to stay in the construction sector than female undergraduates, but the latter had significantly higher financial expectations than their male counterparts. On the other hand, male undergraduates had significantly higher expectations of the number of people they expected to supervise. It was found that professional men were assigned to supervise significantly more people than professional women. In addition, fewer women than men over 36 years were found in the construction industry. Furthermore, it was found that there was slow advancement for women in the Thai construction industry and as a consequence, women engineers left the industry to work in other fields (Ogunlana et al., 1993, Hossain and Kusakabe, 2005). Other studies sought to find out why there were a small number of women in the construction sector, taking into consideration the number of qualified graduates and their turnover rates (Arslan and Kivrak, 2004; Hossain, 2007). It was found that the national religion and culture influenced norms and practices of men and women. The graduation rate of women in Bangladesh was higher than that of women in Thailand because the Bangladeshi government established quotas for women engineers to work in government offices. Families with engineering graduates were considered well-off. Some Bangladeshi women studied engineering because their family members were engineers. Even so, the top priority of women in Bangladesh was to take care of their families, not to work outside their homes. This is consistent with a study by Arslan and Kivrak (2004) of the low employment rates of women engineers in Turkey. Moreover, construction sites in Bangladesh were considered dangerous and unsuitable for women engineers. This was a situation similar to that in South Africa as described by English et al. (2006). As a result, there were even fewer women engineers in the Bangladeshi construction industry than in Thailand despite higher rates of female engineers graduating in Bangladesh.

\section{Challenges Faced by Women Embarking on Non-Traditional Careers in the Construction Industry and Guidelines for Solving Problems}

Inequality in the workplace, sexual harassment and work-life conflict were the major problems confronting women with non-traditional careers. (Gale, 1994; Dainty et al., 1999; Dainty et al.,2001; Bagilhole, 2002; Whitock, 2002; Lingard and Lin, 2004; Dainty et al., 2004; Byrne et

Kaewsri, N and Tongthong, T (2011) 'An investigation of women engineers in non-traditional occupations in the Thai construction industry', Australasian Journal of Construction Economics and Building, 11 (2) 1-21 
al., 2005; Greed, 2006; Dainty and Lingard, 2006; Elvitigala et al., 2006, Madikizela and Haupt, 2010). CEOs of construction and consulting firms interviewed said that the major impediment to the promotion of women engineers was that women left the career track earlier than men (as cited from Khasanet, 1996), pointing to the pressing need to promote equality in the workplace (Agapiou, 2002; Clarke and Gribling, 2008; French and Strachan, 2009), Khazanet undertook research in 1996 into women engineers' work conditions and proposed guidelines for solving the problems which women engineers faced. This study was aimed at bringing about better recognition and promotion opportunities for women engineers and, subsequently, to attract and retain women engineers with valuable experience. Research in the US suggested ways to recruit and retain women engineers (Yates, 2001). A critical pool of women engineers could serve as a focal point to encourage construction companies become more aware of the importance of senior women engineers acting as mentors, advisers and role models in engineering careers for women (Fielden et al., 2000; Dainty et al., 2000a, b; Yates, 2002; Ogunlana et al., 1993; Hossian and Kusakabe, 2005, Dainty and Lingard, 2006). Further studies by Dainty et al. (2000 a, b) suggested that the work culture and structure of the construction industry should be changed to give women more opportunities for career advancement in this sector. Menches and Abraham proposed guidelines for all concerned parties to promote the placement of women in the construction industry to meet future demand (Menches and Abraham, 2007). These guidelines were supported by professional associations, labour unions, and universities.

Nevertheless, there has not been sufficient study of women engineers in non-contractor companies such as consulting companies, real estate developers and construction material suppliers to provide a clear comparison of women engineers working in different types of construction-related businesses. Thus, the present study aims to fill the gaps in previous research by studying women engineers in non-traditional careers, complemented by the experiences of men and women engineers in the Thai construction industry.

\section{Methodology}

\section{Pilot Study}

To obtain data for the pilot study, the researcher interviewed 21 men engineers who were superiors, colleagues and subordinates of women engineers, and 12 women engineers with over five years of experiences in contractor companies. All 21 men engineers acknowledged that women engineers did not enjoy the same benefits as they did. The 11 women engineers $(92 \%)$ of all women engineers who worked in contractor companies felt that they did not advance in their careers as fast as men engineers because of restrictions that precluded them from fulfilling many roles played by men engineers. There were intrinsic and extrinsic factors to be considered. Intrinsic factors included the restraints women engineers put on themselves from doing certain types of work, especially site work. They were not sure whether they could supervise construction projects. They were also unable to work in rural areas because of family commitments. The second factor is extrinsic. Women engineers were not assigned to jobs, such as project supervision, due to the risky nature of the work. Moreover, in Thai culture, it is not common for a woman to be in a job position which is superior to that of a man. Almost all women engineers admitted to experiencing restrictions in their workplaces, thus preventing them from working on construction sites and thus enjoying career advancement. In addition, 12 female engineers found that contractor companies dealt mainly with construction projects. Accordingly, engineers who worked on construction sites received greater recognition from their employers. However, women engineers opined in the interviews that they faced fewer restrictions and enjoyed more opportunities in career advancement in other sub-sectors as such non-contractor businesses (consulting companies, real estate developers and construction material suppliers for example) which placed emphasis on a knowledge of civil engineering or

Kaewsri, N and Tongthong, T (2011) 'An investigation of women engineers in non-traditional occupations in the Thai construction industry', Australasian Journal of Construction Economics and Building, 11 (2) 1-21 
provided a consultancy service based on know-how. Hence, not surprisingly during the pilot study, some women engineers participating in the interviews said that they were looking for positions in consulting companies. There is therefore a need for more research into women engineers working in contractor and non-contractor companies and the turnover rates of men engineers compared to those of women engineers.

\section{Research Design}

As there was no current list of women engineers in the Thai construction industry, it was not possible to carry out a probabilistic random sampling of women engineers working in contractor firms and non-contractor firms in Thailand. Thus a non-probabilistic sampling approach, incorporating a snowball technique, was adopted to select qualified women engineer respondents. Nueman (1994) explained that this technique was both a direct and indirect data collecting technique whereby the first respondent gave new leads for the researcher to further collect information until sufficient information was processed into data for analysis.

For clarity and precision of data, men and women engineers in contractor companies and women engineers working in non-contractor companies in their early careers (that is those with less than ten years of experience) were asked to participate in the research. Most companies participating in this research were located in Bangkok, the capital of Thailand. Semi-structured interviews were employed as the data gathering tool.

The research is divided into three parts. The first part considers two viewpoints about women engineers working in contractor companies and non-contractor companies in terms of career advancement, career path, career difficulties, and problems in non-traditional occupations. The second part considers three viewpoints of men engineers and women engineers who work in contractor companies and of women engineers in non-contractor companies in terms of the appropriateness of women in construction, and opinions about career advancement in the Thai construction industry. Lastly, the third part considers the viewpoints from men engineers and women engineers working in contractor companies in terms of years of working experience and reasons for leaving.

This paper presents a selection of the findings from the full study. Each interview session lasted 30 to 60 minutes. The data gathering process started in July 2008 and was completed in December 2009. The gathered data was analysed using the Statistical Package for the Social Sciences (SPSS) program.

\section{Results}

\section{The samples}

Table 2 shows results of data gathered from 141 civil engineers in Thai construction companies.

The profile of informants comprising civil engineers working in private companies is shown in Table 2. There were 47 male engineers and 47 women engineers working in contractor firms, 47 women engineers who worked in non-contractor firms i.e. 4 women engineers in construction management firms, 2 women engineers in design and inspection firms, 19 women engineers in design and consulting firms, 14 women engineers in real estate companies, 8 women engineers in supply material firms. The total number of civil engineers participating in this research was 141.

In the contractor companies, there were more men who were $23-27$ years old (57\%) than those who were $28-32$ years old (43\%); similarly in contractor companies, there were more women

Kaewsri, N and Tongthong, T (2011) 'An investigation of women engineers in non-traditional occupations in the Thai construction industry', Australasian Journal of Construction Economics and Building, 11 (2) 1-21 
who were $23-27$ years old (62\%) than those who were $28-32$ years old (38\%). However, in the non-contractor companies, there were fewer women engineers who were $23-27$ years old (43\%) than those who were $28-32(55 \%)$ and there was only one woman engineer (2\%) who was more than 32 years old. Most men engineers worked at sites (62\%). Most women worked at headquarter offices, both in contractor companies (55\%) and non-contractor companies (94\%).

\begin{tabular}{|c|c|c|c|c|c|c|c|}
\hline \multirow[t]{2}{*}{ Categories } & \multicolumn{4}{|c|}{ Contractor } & \multicolumn{2}{|c|}{ Non-Contractor } & \multirow{2}{*}{$\begin{array}{l}\text { Total } \\
\text { (person) }\end{array}$} \\
\hline & Men & $\%$ & Women & $\%$ & Women & $\%$ & \\
\hline $\begin{array}{l}\text { 1. Type of Business } \\
\text { 1.1 Contractors } \\
\text { 1.2 Construction Management } \\
\text { 1.3 Consult Design \& Sup. } \\
\text { 1.4 Consult Design } \\
\text { 1.5 Developers } \\
\text { 1.6 Suppliers } \\
\text { Total }\end{array}$ & $\begin{array}{l}47 \\
- \\
- \\
- \\
- \\
- \\
47\end{array}$ & 100 & 47 & 100 & $\begin{array}{c}- \\
4 \\
2 \\
19 \\
14 \\
8 \\
47\end{array}$ & $\begin{array}{c}- \\
9 \\
4 \\
40 \\
29 \\
17 \\
100\end{array}$ & $\begin{array}{c}94 \\
4 \\
2 \\
19 \\
14 \\
8 \\
141\end{array}$ \\
\hline $\begin{array}{l}\text { 2. Age } \\
2.123-27 \mathrm{yr} \\
2.228-32 \mathrm{yr} \\
2.333-37 \mathrm{yr} \\
\text { Total }\end{array}$ & $\begin{array}{l}27 \\
20 \\
- \\
47\end{array}$ & $\begin{array}{c}51 \\
49 \\
- \\
100\end{array}$ & $\begin{array}{l}29 \\
18 \\
- \\
47\end{array}$ & $\begin{array}{c}62 \\
38 \\
- \\
100\end{array}$ & $\begin{array}{c}20 \\
26 \\
1 \\
47\end{array}$ & $\begin{array}{c}43 \\
57 \\
2 \\
100\end{array}$ & $\begin{array}{c}76 \\
64 \\
1 \\
141\end{array}$ \\
\hline $\begin{array}{l}\text { 3. Work Location } \\
\text { 3.1 Head Office } \\
\text { 3.2 Site Office } \\
\text { 3.3 On-Site } \\
\text { Total }\end{array}$ & $\begin{array}{c}16 \\
2 \\
29 \\
47\end{array}$ & $\begin{array}{c}34 \\
4 \\
62 \\
100\end{array}$ & $\begin{array}{c}26 \\
20 \\
1 \\
47\end{array}$ & $\begin{array}{c}55 \\
43 \\
2 \\
100\end{array}$ & $\begin{array}{c}44 \\
3 \\
- \\
47\end{array}$ & $\begin{array}{c}94 \\
6 \\
- \\
100\end{array}$ & $\begin{array}{c}86 \\
25 \\
30 \\
141\end{array}$ \\
\hline $\begin{array}{l}\text { 4. Marital Status } \\
4.1 \text { Single } \\
4.2 \text { Married } \\
\text { Total }\end{array}$ & $\begin{array}{l}33 \\
14 \\
47\end{array}$ & $\begin{array}{c}70 \\
30 \\
100\end{array}$ & $\begin{array}{c}40 \\
7 \\
47\end{array}$ & $\begin{array}{c}85 \\
15 \\
100\end{array}$ & $\begin{array}{l}36 \\
11 \\
47\end{array}$ & $\begin{array}{c}77 \\
23 \\
100\end{array}$ & $\begin{array}{c}109 \\
32 \\
141\end{array}$ \\
\hline $\begin{array}{l}\text { 5. Family Responsibility } \\
5.1 \text { No responsibility } \\
\text { 5.2 Elderly care } \\
\text { 5.3 Child care } \\
5.4 \text { Both child and elderly care } \\
\text { Total }\end{array}$ & $\begin{array}{c}41 \\
3 \\
3 \\
- \\
47\end{array}$ & $\begin{array}{c}87 \\
6 \\
6 \\
- \\
100\end{array}$ & $\begin{array}{c}32 \\
11 \\
3 \\
1 \\
47\end{array}$ & $\begin{array}{c}68 \\
24 \\
6 \\
2 \\
100\end{array}$ & $\begin{array}{l}34 \\
5 \\
8 \\
- \\
47\end{array}$ & $\begin{array}{c}72 \\
11 \\
17 \\
- \\
100\end{array}$ & $\begin{array}{c}107 \\
19 \\
14 \\
1 \\
141\end{array}$ \\
\hline $\begin{array}{l}\text { 6. Education level } \\
6.1 \text { Bachelor } \\
6.2 \text { Master } \\
6.3 \text { Others..Studying master } \\
\text { Total }\end{array}$ & $\begin{array}{c}28 \\
15 \\
4 \\
47\end{array}$ & $\begin{array}{c}60 \\
31 \\
9 \\
100\end{array}$ & $\begin{array}{l}34 \\
9 \\
4 \\
47\end{array}$ & $\begin{array}{c}72 \\
19 \\
9 \\
100\end{array}$ & $\begin{array}{l}22 \\
20 \\
5 \\
47\end{array}$ & $\begin{array}{c}47 \\
43 \\
10 \\
100\end{array}$ & $\begin{array}{c}84 \\
44 \\
13 \\
141\end{array}$ \\
\hline $\begin{array}{l}\text { 7. Salary (Baht / month) } \\
7.110,000-20,000 \\
7.221,000-50,000 \\
7.351,000-100,000 \\
\text { Total }\end{array}$ & $\begin{array}{c}11 \\
30 \\
6 \\
47\end{array}$ & $\begin{array}{c}23 \\
64 \\
13 \\
100\end{array}$ & $\begin{array}{c}23 \\
23 \\
1 \\
47\end{array}$ & $\begin{array}{c}49 \\
49 \\
2 \\
100\end{array}$ & $\begin{array}{c}9 \\
36 \\
2 \\
47\end{array}$ & $\begin{array}{c}19 \\
77 \\
4 \\
100\end{array}$ & $\begin{array}{c}43 \\
89 \\
9 \\
141\end{array}$ \\
\hline $\begin{array}{l}\text { 8. Site work experience } \\
8.10-1 \mathrm{yr} \text {. } \\
8.22-4 \mathrm{yr} \text {. } \\
8.35-10 \mathrm{yr} \text {. } \\
\text { Total }\end{array}$ & $\begin{array}{l}7 \\
21 \\
19 \\
47\end{array}$ & $\begin{array}{c}15 \\
45 \\
40 \\
100\end{array}$ & $\begin{array}{c}37 \\
9 \\
1 \\
47\end{array}$ & $\begin{array}{c}79 \\
19 \\
2 \\
100\end{array}$ & $\begin{array}{l}43 \\
4 \\
- \\
47\end{array}$ & $\begin{array}{c}91 \\
9 \\
- \\
100\end{array}$ & $\begin{array}{c}87 \\
34 \\
20 \\
141\end{array}$ \\
\hline $\begin{array}{l}\text { 9. Tenure } \\
9.10-1 \mathrm{yr} \text {. } \\
9.22-4 \mathrm{yr} \text {. } \\
9.35-10 \mathrm{yr} \text {. } \\
\text { Total }\end{array}$ & $\begin{array}{c}13 \\
29 \\
5 \\
47\end{array}$ & $\begin{array}{c}28 \\
62 \\
10 \\
100 \\
\end{array}$ & $\begin{array}{c}28 \\
16 \\
3 \\
47\end{array}$ & $\begin{array}{c}60 \\
34 \\
6 \\
100 \\
\end{array}$ & $\begin{array}{c}27 \\
17 \\
3 \\
47 \\
\end{array}$ & $\begin{array}{c}57 \\
36 \\
6 \\
100 \\
\end{array}$ & $\begin{array}{c}68 \\
62 \\
21 \\
141 \\
\end{array}$ \\
\hline
\end{tabular}

Table 2 Informant profiles

Kaewsri, N and Tongthong, T (2011) 'An investigation of women engineers in non-traditional occupations in the Thai construction industry', Australasian Journal of Construction Economics and Building, 11 (2) 1-21 
As for marital status, most men were single (70\%) and most women (85\%) in contractor companies were single, while in non- contractor companies 77 per cent of the women were single. Regarding family responsibilities, most men engineers (87\%) and women engineers $(68 \%)$ in contractor companies and women engineers $(72 \%)$ in non-contractor companies did not have family responsibilities. With reference to education levels, there were more men in contractor companies who had Bachelor's degrees (60\%) than those with Master's degrees $(32 \%)$ and those who were studying for Master's degrees (9\%). Likewise, in contractor companies, there were significantly more women who had Bachelor's degrees $(72 \%)$ than those with Master's degrees (18\%). However, in non-contractor companies, the percentage of women with Bachelor's degrees $(47 \%)$ was only slightly higher than that of women with Master's degrees (43\%); women who were studying for Master's degrees $(6 \%)$ were only slightly fewer than men who are pursuing their Master's degrees (9\%).

In regard to salaries (Baht per month), most men engineers (64\%) and women engineers (77\%) in non-contractor companies had salaries of 21,000-50,000 Baht / month. However, among women engineers in contractor companies, about half of them had salaries in the range of 10,000-20,000 Baht / month and another half drew salaries of 21,000-50,000 Baht / month (Table 1).

Regarding site work experience, most women in contractor (79\%) and non-contractor companies $(91 \%)$ had $0-1$ year experience. Most women $(62 \%)$ who worked in non-contractor companies did not have site work experience and, there was only one woman engineer in contractor companies in the 5 -10 year experience category. Regarding men engineers with site work experience, 40 per cent of them had worked 5 - 10 years; those who had 2 - 4 years' site work experience made up 45 per cent of the male engineering workforce.

Finally, tenure was analysed. Most men (62\%) had worked in the same positions for 2-4 years while 28 per cent of them had worked in the same positions for 0 to 1 year, and 10 per cent were in the 5-10 year category. As for women engineers, 60 per cent of them had worked in the same positions for 0 to 1 year in contractor companies. In non-contractor companies, the figure was 57 per cent.

\section{A Comparison of the Viewpoints of Women Engineers in Contractor Companies with Those of Their Counterparts in Non-Contractor Companies}

The data in this section were derived from interview sessions with 47 women engineers working in contractor companies and 47 women engineers working in non-contractor companies. Questions for the interviews were based on selected topics such as difficulties encountered in civil engineering careers, problems in non-traditional careers, career progression of women engineers compared with men engineers and careers guidelines for employees. Each topic is discussed below.

\section{Career challenges in the Thai construction industry}

Difficulties of working in the construction industry with regard to studying civil engineering, job application and career success in the Thai construction industry are illustrated in Table 3.

As shown in Table 3, women engineers faced many challenges if they aspired to be employed in the Thai construction industry. The difficulties were in the following areas:

Studying civil engineering field: When they were civil engineering undergraduates, the top three difficulties for women engineers in contractor companies and non-contractor companies were: studying in laboratories where they had to carry heavy materials such as cement blocks,

Kaewsri, N and Tongthong, T (2011) 'An investigation of women engineers in non-traditional occupations in the Thai construction industry', Australasian Journal of Construction Economics and Building, 11 (2) 1-21 
studying in the sun, self-perceived slower pace of learning and self-perceived lack of talent compared to their male counterparts. According to the two viewpoints, it can be concluded that women engineers working in both contractor companies and non-contractor companies had more or less similar difficulties at the time they were studying civil engineering.

Job application: The top three difficulties for women engineers working in contractor companies were: preference for men engineers by most companies, fewer positions for women engineers in contractor companies and preference for graduates from public universities by most companies. As for women engineers working in non-contractor companies, the three major difficulties were preference for graduates from public universities by most companies, making it harder for women graduating from private universities to get a job, difficulty of employment after graduation and preference for people with hands-on experience. It can be concluded that the top three difficulties faced by women engineers working in contractor companies were different from those of women engineers working in non-contractor companies.

\begin{tabular}{|c|c|c|}
\hline Difficulties & Score & Rank \\
\hline $\begin{array}{l}\text { 1. Civil Engineering Undergraduate : } \\
\text { Contractor } \\
\text { 1. Impatient when conducting studies outdoors or in the sun } \\
\text { 2. Unable to do heavy work in laboratories, such carrying heavy } \\
\text { instruments or materials } \\
\text { 3. Perceived as slower learners in laboratories and less talented } \\
\text { compared to men engineers } \\
\text { Non-contractor } \\
\text { 1. Unable to perform certain physical tasks such carrying heavy } \\
\text { instruments or materials } \\
\text { 2. Impatient when studying outdoors or in the sun } \\
\text { 3. Perceived as slower learners in laboratories and less talented } \\
\text { compared to men engineers }\end{array}$ & $\begin{array}{l}16 \\
11 \\
9\end{array}$ & $\begin{array}{l}1 \\
2 \\
3\end{array}$ \\
\hline $\begin{array}{l}\text { 2. Job Application: } \\
\text { Contractor } \\
\text { 1. Preference of men to women engineers by contractor } \\
\text { companies } \\
\text { 2. Fewer positions open to women engineers } \\
\text { 3. Preference of graduates from public universities by contractor } \\
\text { companies } \\
\text { Non-Contractor } \\
\text { 1. Preference of graduates from public universities by contractor } \\
\text { companies } \\
\text { 2. Difficulty of finding jobs immediately after graduation } \\
\text { 3. Preference of applicants with hands-on experience }\end{array}$ & $\begin{array}{l}31 \\
23 \\
18\end{array}$ & $\begin{array}{l}1 \\
2 \\
3\end{array}$ \\
\hline $\begin{array}{l}\text { 3. Success in working: } \\
\text { Contractor } \\
\text { 1. Little knowledge of site work made work difficult } \\
\text { 2. Greater difficulty in controlling subordinates compared to men } \\
\text { 3. Difficulty in receiving recognition from superiors or subordinates } \\
\text { Non-contractor } \\
\text { 1. During site inspection contractors and workers gave less } \\
\text { respect to women engineers } \\
\text { 2. Little knowledge of site work made work difficult } \\
\text { 3. Difficulty in receiving recognition from superiors or subordinates }\end{array}$ & $\begin{array}{l}27 \\
19 \\
18\end{array}$ & $\begin{array}{l}1 \\
2 \\
3\end{array}$ \\
\hline
\end{tabular}

Table 3 Career challenges faced by women in the Thai construction industry

Kaewsri, $\mathrm{N}$ and Tongthong, $\mathrm{T}$ (2011) 'An investigation of women engineers in non-traditional occupations in the Thai construction industry', Australasian Journal of Construction Economics and Building, 11 (2) 1-21 
Working for success: The most serious problem for women engineers in contractor companies was limited knowledge about site work, followed by difficulty of controlling subordinates compared to men engineers. The third challenge was the difficulty of getting recognition from superiors and subordinates. Women engineers working in non-contractor companies stated that the number one problem they had was little recognition from contractors during site inspection, followed by limited knowledge about site work. The third problem was the difficulty of getting recognition from superiors or subordinates. Hence, there was similarity in the first three difficulties confronted by women engineers working in contractor companies and non-contractor companies.

\section{Experience of problems in Non-Traditional careers}

Challenges faced by women with non-traditional careers in the construction industry, specifically sexual harassment, work-family conflicts and inequality at work are shown in Table 4.

\begin{tabular}{|l|c|c|c|c|}
\hline \multirow{2}{*}{ Obstacles } & \multicolumn{2}{c|}{ Contractor } & \multicolumn{2}{c|}{ Non-Contractor } \\
\cline { 2 - 5 } & Number & Per cent & Number & Per cent \\
\hline $\begin{array}{l}\text { Sexual Harassment } \\
\quad \text { Presence }\end{array}$ & 11 & & & \\
$\quad$ Absence & 36 & 77 & 6 & 13 \\
$\quad$ Total & 47 & 100 & 47 & 87 \\
\hline Work-Family Conflict & & & & 100 \\
$\quad$ Presence & 12 & 26 & 3 & 6 \\
$\quad$ Absence & 35 & 74 & 44 & 94 \\
$\quad$ Total & 47 & 100 & 47 & 100 \\
\hline Equality of Opportunities & & & & \\
$\quad$ Equal & 3 & 6 & 36 & 77 \\
$\quad$ Not equal & 44 & 94 & 11 & 23 \\
$\quad$ Total & 47 & 100 & 47 & 100 \\
\hline
\end{tabular}

Table 4 Obstacles in non-traditional careers in the construction industry

Table 4 summarises the problems women engineers faced in non-traditional careers the Thai construction industry. More specifically, the problems were in the following areas:

Sexual harassment: Twenty-three per cent of all women engineers working in contractor companies felt sexually harassed. Examples of harassing behaviours were flirting, talking in a sexual way, touching bodies, touching hands, requesting women engineers to stay late to work, asking women engineers to become minor wives, offers of financial support with suspect motives. In one case, a women engineer was asked to take care of a consultant who was flirtatious. However, 77 per cent all women engineers working in contractor companies did not feel sexually harassed in their workplaces, saying that civil engineering was a prestigious profession and that they felt respected.

When asked about sexual harassment, 13 per cent of the women engineers in non-contractor companies stated that there was sexual harassment in their workplaces. They gave examples like dirty talk, inappropriate description of bodies, trying to have dinner dates with women engineers, asking them about their love life, etc. While 87 per cent of women engineers working in non-contractor companies did not experience sexual harassment in their workplaces, adding that most people respected them as civil engineers. However, they mentioned that women in other positions such as secretaries were sexually harassed if they did not know how to conduct

Kaewsri, N and Tongthong, T (2011) 'An investigation of women engineers in non-traditional occupations in the Thai construction industry', Australasian Journal of Construction Economics and Building, 11 (2) 1-21 
themselves. Apparently, the percentage of women engineers who experienced sexual harassment was higher for those working in contractor firms than in non-contractor companies.

Work-life conflict: Twenty-six per cent of women engineers in contractor companies had to deal with work-family conflicts in their workplaces, such as working upcountry for lengthy periods while having to take care of family responsibilities at the same time, uncertain working hours which made it difficult for women to take care of their children and their parents, and working over the weekends. Sometimes women engineers had to work late into the night to compete with their male counterparts for recognition and promotion. However, unlike women engineers, men engineers did not have similar family responsibilities. Some problems were inevitable such as working in remote places. It should be noted that 74 per cent of all women engineers in contractor companies said that they did not have work-family conflicts as they did not have family responsibilities.

On the other hand, 6 per cent of the women engineers in non-contractor companies stated that they had work-family conflicts such as having to care for very young children who required much of their time and attention, busy husbands who had no time to help with family chores, and taking care of sickly or elderly parents. Ninety-four percent of all women engineers in noncontractor companies said that they did not have work-family conflicts because they did not have unmanageable family responsibilities. They also did not have high workloads all the time and most companies gave them two days off per week so that they could attend to family matters. Therefore, it can be seen that women engineers working in contractor companies had slightly more work/family conflicts than their female peers in non-contractor companies.

Equality of opportunities: Only six per cent of women engineers from contractor companies thought that there was equality of opportunities, adding that they had good and efficient superiors who treated everybody equally, and their companies gave both sexes equal opportunities to work both on site and in the office. However, the majority (94\%) of women engineers working in contractor companies opined that there was no sexual equality in their workplaces. They gave the following reasons in descending order. Most of the time, contractor companies preferred to hire men engineers. Even if they did get hired, women engineers were hardly ever assigned to work on construction sites. The more important jobs were usually given to men engineers. Organizations and male superiors seemed have a mindset about men engineers being more efficient than their female counterparts. They held the view that women engineers were incapable of supervising subordinates because they did not have enough leadership qualities and were unable to get acceptance from subordinates, superiors and colleagues. In addition, the opinions of women engineers were seldom taken into consideration.

On the other hand, there was a very different picture in the non-contractor companies. Seventyseven per cent of the women engineers enjoyed equality in their workplaces. They said they could compete with men equally for all the positions. In their view, women were more suitable for this profession because they had good communication and coordination skills, which could reduce communication mistakes. With good and fair-minded superiors, they also had equal opportunities to get promoted and enjoy salary increments. Nevertheless, 23 per cent of all women engineers working in non-contractor companies opined that there was no sexual equality in their workplaces. They stated that superiors thought that women did not have enough leadership ability. They also thought that women were highly discriminated against in their workplaces, and there were a lot of jobs that were considered unsuitable for women. According to this group of women engineers, they were hardly ever given important jobs; neither did they receive recognition from superiors, colleagues, customers or project owners.

Kaewsri, N and Tongthong, T (2011) 'An investigation of women engineers in non-traditional occupations in the Thai construction industry', Australasian Journal of Construction Economics and Building, 11 (2) 1-21 
Therefore, women engineers working in contractor companies had different perceptions about equality in workplaces from those of women engineers in non-working contractor companies. There seemed to be more inequality for women engineers working in contractor companies. On the other hand, the majority of women engineers working in non-contractor companies opined that there was equality in their workplaces.

\section{Career progression}

Prospects for career progression of women engineers compared with those of men engineers are shown in Table 5.

\begin{tabular}{|c|c|c|c|c|}
\hline \multirow{2}{*}{ Career Progression } & \multicolumn{2}{|c|}{ Contractor } & \multicolumn{2}{|c|}{ Non-Contractor } \\
\hline & Number & Per cent & Number & Per cent \\
\hline $\begin{array}{l}\text { Had equal career advancement compared to } \\
\text { men engineers }\end{array}$ & 8 & 17 & 22 & 47 \\
\hline $\begin{array}{l}\text { Had less career advancement compared to } \\
\text { men engineers }\end{array}$ & 39 & 83 & 25 & 53 \\
\hline Total & 47 & 100 & 47 & 100 \\
\hline
\end{tabular}

Table 5 Women engineers' views of career advancement

Table 5 shows the percentage of women engineers from contractor companies who felt that they had fewer career advancement opportunities compared to men engineers was significantly higher $(83 \%)$ than women engineers who thought that they had equal career advancement to men engineers (17\%). Interestingly, women engineers in the non-contractor companies did not differ very much in their views regarding career advancement, with 47 per cent thinking that they had equal career advancement to men, while 53 per cent thought otherwise. The reasons put forth by women engineers who felt that they had equal career advancement as men engineers were:

- Their companies gave similar assignments to both men and women engineers and offered the same starting salaries and performance-based increments. Sometimes they even had higher salary raises than men engineers.

On the other hand, women engineers who felt that they did not have equal career advancement compared to men engineers gave the following reasons:

- Women engineers imposed limitations on themselves. They did not feel confident enough to handle certain tasks as they were not sure whether they could work with subcontractors and supervise subordinates; they disliked the physical conditions of site work as they thought that construction sites were dirty and dangerous for women.

- Most of the time, men engineers were assigned to do more important jobs than women engineers especially at construction sites where men predominate. Women engineers were not assigned to supervise projects and male workers. Unlike their male counterparts, women engineers did not have a clear understanding about construction methods due to their lack of site work experience. Subsequently, they could not carry out as many tasks as men could.

Nevertheless, women engineers who worked in contractor and non-contractor companies admitted that site work experience was important for their career advancement and 
performance. Women engineers who did not have direct site-based work experience sought new knowledge from site visits, self-study and the Internet. Some companies even provided mentors for them so they could improve their performance and productivity.

\section{Career path}

Career path guidelines provided by construction companies for women engineers are shown in Table 6.

\begin{tabular}{|c|c|c|c|c|}
\hline \multirow{2}{*}{ Career Path } & \multicolumn{2}{|c|}{ Contractor } & \multicolumn{2}{c|}{ Non-Contractor } \\
\cline { 2 - 5 } & Number & Per cent & Number & Per cent \\
\hline Yes & 4 & 9 & 18 & 38 \\
\hline No & 43 & 91 & 29 & 62 \\
\hline Total & 47 & 100 & 47 & 100 \\
\hline
\end{tabular}

Table 6 Women engineers who had career path guidelines

As shown in Table 6, only 9 per cent of contractor companies developed career path guidelines for women engineers. However, the percentage was higher (38\%) in non-contractor companies. It can be concluded that non-contractor companies developed more career path guidelines for women engineers than contractor companies. Normally, most companies developed career path guidelines for employees who held key positions in the companies in order to retain and motivate them. Hence from the data collected, it was implied that, unlike contractor companies, non-construction companies placed more emphasis on the potential roles of women engineers in Thailand.

\section{Comparison of the Views of Men and Women Engineers in Contractor Companies} with Those of Women Engineers in Non-Contractor Companies

This section discusses appropriateness of women working as civil engineers. Opinions regarding this issue were gathered from 47 women engineers and 47 men engineers working in contractor companies, and 47 women engineers working in non-contractor companies about career success in the Thai construction industry. The data are discussed in detail as below.

\section{Careers in construction}

Information regarding the appropriateness of women engineers working as civil engineers is shown in Table 7.

\begin{tabular}{|c|c|c|c|c|c|c|}
\hline \multirow{2}{*}{ Women should be civil engineers } & \multicolumn{4}{|c|}{ Contractor } & \multicolumn{2}{c|}{ Non-Contractor } \\
\cline { 2 - 7 } & \multicolumn{2}{|c|}{ Men } & \multicolumn{2}{c|}{ Women } & \multicolumn{2}{c|}{ Women } \\
\cline { 2 - 7 } & No. & Per cent & No. & Per cent & No. & Per cent \\
\hline Should be & 7 & 15 & 16 & 34 & 34 & 72 \\
\hline Should not be & 40 & 85 & 31 & 66 & 13 & 28 \\
\hline Total & 47 & 100 & 47 & 100 & 47 & 100 \\
\hline
\end{tabular}

Table 7 Appropriateness of women working as civil engineers

From Table 7, it can be seen that only 15 per cent of all men engineers working in contractor companies thought that women should be civil engineers. However, the majority of them

Kaewsri, N and Tongthong, T (2011) 'An investigation of women engineers in non-traditional occupations in the Thai construction industry', Australasian Journal of Construction Economics and Building, 11 (2) 1-21 
thought that civil engineering work was only suitable for women engineers working in noncontractor companies, doing various supportive and productive work, which were equally important and indispensable in construction projects. Nevertheless, 85 per cent of the men thought that women should not be civil engineers in contractor firms, stating that construction projects in contractor companies required engineers to be physically strong. They stated that civil engineering jobs including estimation, procurement-recruitment, coordination, inspection, planning and monitoring, design and documentation work were more appropriate for women engineers. Therefore, it was felt that if women engineers could coordinate their work with their male counterparts in contractor companies, mistakes could be mitigated.

As far as women engineers in contractor firms were concerned, 66 per cent of them thought that women should not be civil engineers. They felt that they were underachieving because they were not given the opportunity to advance. Their scope of work was limited as site work was regarded as inappropriate for women, who were generally considered the weaker sex. Hence, women engineers were of the view that they had limited career advancement. Furthermore, women engineers thought that there was sexual inequality in contractor companies. According to a woman engineer who was interviewed:

"I don't encourage women to do this job. If you do not have dark skin, or if you are not fat and gay-like or tomboyish, you will have big problems when working in a contractor company. Out of the three companies I have worked for, I have never seen any women civil engineers in high positions except for those who have their own businesses. Being merely an employee leaves you with little chance of career advancement."

On the other hand, 72 per cent of women engineers working in non-contractor companies said that women should become civil engineers. They stated that civil engineering was a field with work including designing, inspection, planning and supervising. In their opinion, women would do well in this profession because they had good communication and coordination skills, which would reduce communication mistakes. Feminine strengths, namely tact, honesty, tidiness and English proficiency, could mitigate men engineers' mistakes and complement their work. Due to a wide range of jobs in civil engineering, the women engineers interviewed felt that they should, nevertheless, seek to have more experience and knowledge from site work and other sources so they could be proud of their careers, as traditionally this profession belonged to men. However, 28 per cent of women engineers working in non-contractor companies thought that women should not become civil engineers, saying that most construction companies put more trust in men civil engineers, so women engineers did not receive recognition and advancement in their careers as men did.

Thus there were different viewpoints about women in civil engineering. Both men engineers $(85 \%)$ and women engineers (66\%) working in contractor companies thought that women should not be civil engineers. Women engineers working in non-contractor companies, however, thought otherwise. In fact, 72 per cent of them thought that women should be civil engineers.

\section{Career progression in the Thai construction industry}

Table 8 explains and compares opinions about working in non-traditional careers like the construction industry of men and women engineers in contractor companies and women engineers working in non-contractor companies. Eight topics were asked using a 5-point rating scale. The details are in Table 8.

The feedback for each statement in the table 8 is explained as follows:

Kaewsri, N and Tongthong, T (2011) 'An investigation of women engineers in non-traditional occupations in the Thai construction industry', Australasian Journal of Construction Economics and Building, 11 (2) 1-21 
1. To be successful career in civil engineering, one must have site work experience. When the mean $(\mu)$ was taken into consideration, it was found that men engineers working in contractor companies had the highest mean $(\mu=4.34)$, followed by women engineers working in contractor companies ( $\mu=4.28)$, and women engineers working in non-contractor companies $(\mu=3.15)$. This shows that both men and women engineers working in contractor companies ranked, at the highest level, the statement that to be successful in civil engineering careers they must have site work experience, whilst women engineers working in non-contractor companies gave an average rating to this opinion.

\begin{tabular}{|c|c|c|c|c|c|c|}
\hline \multirow{3}{*}{ Descriptions } & \multicolumn{4}{|c|}{ Contractor } & \multirow{2}{*}{\multicolumn{2}{|c|}{$\begin{array}{c}\text { Non-Contractor } \\
\text { Women }\end{array}$}} \\
\hline & \multicolumn{2}{|c|}{ Men } & \multicolumn{2}{|c|}{ Women } & & \\
\hline & Mean & S.D. & Mean & S.D. & Mean & S.D. \\
\hline $\begin{array}{l}\text { 1. To be successful in civil engineering, one } \\
\text { must have site work experience }\end{array}$ & 4.34 & 0.479 & 4.28 & 0.452 & 3.15 & 0.751 \\
\hline $\begin{array}{l}\text { 2. Having no site work experience in the } \\
\text { long run can make one lose confidence in } \\
\text { work }\end{array}$ & 3.43 & 0.500 & 3.15 & 0.416 & 2.45 & 0.544 \\
\hline $\begin{array}{l}\text { 3. People with site work experiences have } \\
\text { more chances of promotions and salary } \\
\text { raises }\end{array}$ & 4.23 & 0.428 & 4.38 & 0.491 & 3.64 & 0.486 \\
\hline $\begin{array}{l}\text { 4. Companies gain equal benefits from } \\
\text { Women and men engineers }\end{array}$ & 4.94 & 0.247 & 4.34 & 0.522 & 4.57 & 0.500 \\
\hline $\begin{array}{l}\text { 5. Getting promoted (from associate } \\
\text { engineers to professional and } \\
\text { professional to charter engineers) leads to } \\
\text { career advancement }\end{array}$ & 4.36 & 0.486 & 4.13 & 0.337 & 3.74 & 1.010 \\
\hline $\begin{array}{l}\text { 6. Civil engineering is unsuitable for women } \\
\text { because career advancement is limited to } \\
\text { men }\end{array}$ & 2.83 & 0.842 & 2.89 & 0.729 & 2.47 & 0.687 \\
\hline $\begin{array}{l}\text { 7. Civil engineering is unsuitable for women } \\
\text { because of limitations like dislike of } \\
\text { working outdoors, fear of climbing, etc. }\end{array}$ & 3.79 & 0.414 & 3.18 & 0.613 & 3.00 & 0.659 \\
\hline $\begin{array}{l}\text { 8. Overall satisfaction with work in } \\
\text { construction industry }\end{array}$ & 3.68 & 0.663 & 3.28 & 0.649 & 3.91 & 0.408 \\
\hline
\end{tabular}

Table 8 Working for progression in the Thai construction industry

* The level of mean interpreted as include; $1.0-1.79=$ lowest, $1.80-2.59=$ low, $2.60-3.39=$ average, $3.40-4.19=$ high, 4.20-5.00 = highest

2. Having no site work experience in the long run can make one lose confidence in work. When the mean $(\mu)$ was taken into account, it was found that men engineers working in contractor companies had the highest mean $(\mu=3.43)$, followed by women engineers working in contractor companies $(\mu=3.15)$, and women engineers working in non-contractor companies $(\mu=2.45)$. This shows that both men and women engineers working in contractor companies agreed, on an average level, that having no site work experience in the long run could make them lose confidence in their jobs, while women engineers working in non-contractor companies rated their agreement with at a low level.

3. People with site work experience have more chances of promotion and salary raises compared to those without site work experience. When the mean $(\mu)$ was taken into account, it

Kaewsri, N and Tongthong, T (2011) 'An investigation of women engineers in non-traditional occupations in the Thai construction industry', Australasian Journal of Construction Economics and Building, 11 (2) 1-21 
was found that women engineers working in contractor companies had the highest mean ( $\mu=4.34)$, followed by men engineers working in contractor companies $(\mu=4.28)$, and women engineers working in non-contractor companies $(\mu=3.64)$. This shows that both men and women engineers working in contractor companies agreed with the statement and rated it at the highest level i.e. they were very much in agreement that people with site work experience had better chances of promotions and salary raises compared to those without site work experience; women engineers working in non-contractor companies also agreed with this statement and rated it at a high level.

4. Companies gain equal benefits from women and men engineers. When the mean $(\mu)$ was taken into consideration, it was found that men engineers working in contractor companies had the highest mean $(\mu=4.94)$, followed by women engineers working in non-contractor companies $(\mu=4.57)$, and women engineers working in contractor companies $(\mu=4.34)$. This shows that both men and women engineers working in contractor and non-contractor companies agreed, at the highest level, that companies gain equal benefits from women and men engineers.

5. Getting promoted to higher levels (from associate to professional and from professional to chartered) leads to career advancement. When the mean $(\mu)$ was taken into account, it was found that men engineers working in contractor companies had the highest mean $(\mu=4.36)$, followed by women engineers working in contractor companies $(\mu=4.13)$, and women engineers working in non-contractor companies $(\mu=3.74)$. This shows that men engineers and women engineers working in contractor companies and women engineers working in non-contractor companies had different ideas about the statement "Getting promoted to higher levels (from associate to professional and from professional to chartered) leads to career advancement." Men engineers working in contractor companies ranked their agreement with that statement at the highest level while women engineers working in contractor companies and women engineers working in non-contractor companies agreed with the statement at a high level.

6. Civil engineering is unsuitable for women because career advancement is limited to men. When the mean $(\mu)$ was considered, it was found that women engineers working in contractor companies had the highest mean $(\mu=2.83)$, followed by men engineers working in contractor companies ( $\mu=2.89)$, and women engineers working in non-contractor companies $(\mu=2.47)$. This shows that men engineers and women engineers working in contractor companies agreed, at an average level, that civil engineering was unsuitable for women because career advancement was confined to men; women engineers working in non-contractor companies agreed with the statement at a low level.

7. Civil engineering is unsuitable for women because women have limitations such as climbing to high places, etc. When mean $(\mu)$ was taken into consideration, it was found that women engineers working in contractor companies had the highest mean $(\mu=3.81)$, followed by men engineers working in contractor companies $(\mu=3.79)$, and women engineers working in noncontractor companies $(\mu=3.00)$. This shows that both men and women engineers working in contractor companies rated their agreement with the statement at a high level whilst women engineers working in non-contractor companies gave an average rating for their agreement.

8. Overall satisfaction with work in the construction industry. When the mean $(\mu)$ was taken into account, it was found that women engineers working in non-contractor companies had the highest mean $(\mu=3.91)$, followed by men engineers working in contractor companies $(\mu=3.68)$, and women engineers working in contractor companies $(\mu=3.28)$. This shows that women

Kaewsri, N and Tongthong, T (2011) 'An investigation of women engineers in non-traditional occupations in the Thai construction industry', Australasian Journal of Construction Economics and Building, 11 (2) 1-21 
engineers working in non-contractor companies and men engineers working in contractor companies enjoyed a high level of overall work satisfaction, whilst women engineers working in contractor companies thought that their overall work satisfaction was at an average level.

\section{Comparison of Turnover Rates of Women and Men Engineers Working in Contractor Companies}

The data on the turnover rates and reasons for their turnover were collected from a survey of women engineers and men engineers working in contractor companies. Turnover rates of 47 women and 47 men below 32 years of age, or in their first ten years of working, were compared. These values were based on the average duration that an engineer remained in service with one company, and were calculated using the following Formula 1.

$$
\begin{aligned}
& \text { (current age - age upon bachelor's degree completion } \\
& \text { - No. of years of higher education } \\
& \text { Average years of working }=\frac{- \text { No.of years of being job less })}{\text { No.of companies an individual has work for }} \quad\left(\frac{\text { years }}{\text { company }}\right)
\end{aligned}
$$

The results obtained by using Formula 1 giving the average years of working for one company of men and women engineers are analyzed and presented in Figure 1.

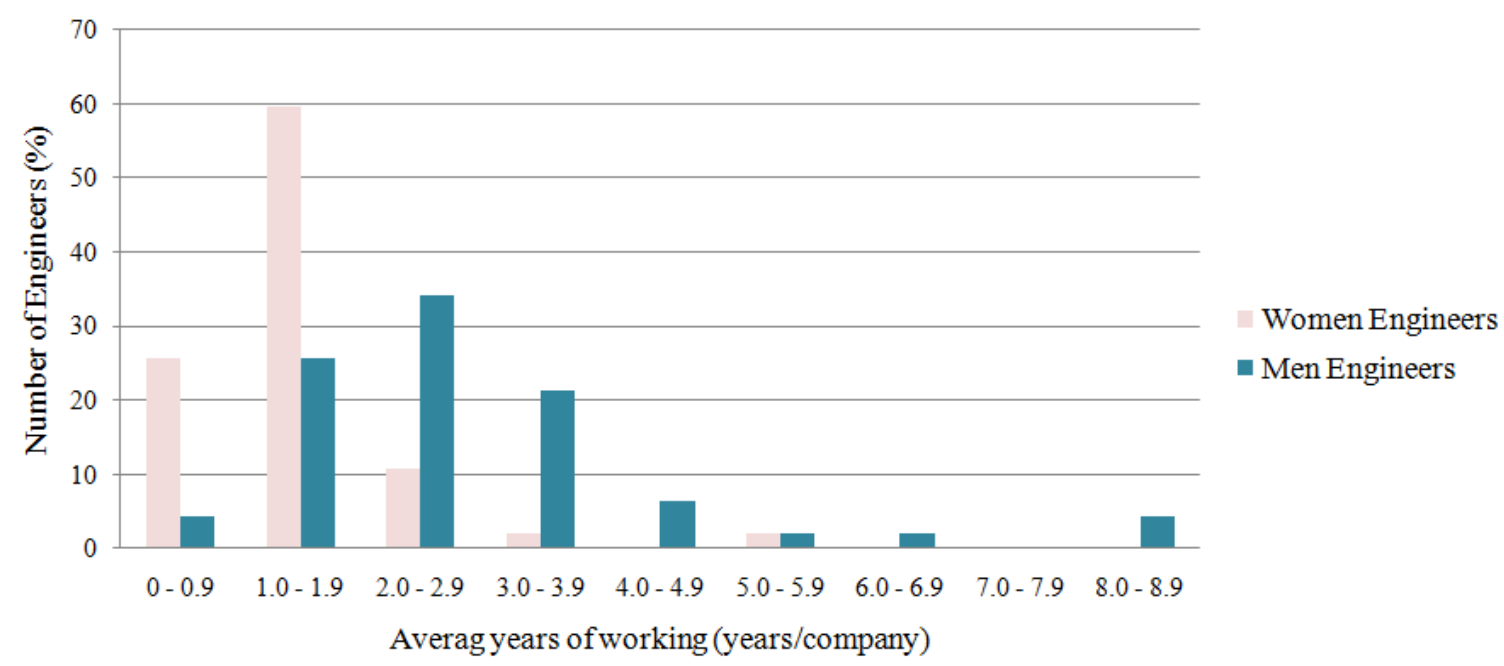

Figure 1 Comparison of average working years of men and women engineers in one company

It can be seen from Figure 1 that more than $80 \%$ of women engineers had worked in one company for less than two years; $26 \%$ of women engineers had worked in one company less than one year. The graph also reveals that $60 \%$ of women engineers had worked in a company for 1.0-1.9 years. As for men engineers, the graph shows that over $80 \%$ of them had worked in one company for 1.0-3.9 years; $26 \%$ of them had worked in one company for $1.0-1.9$ years; $34 \%$ of them had worked in one company for $2.0-2.9$ years; and $21 \%$ of them had worked in one company for 3.0-3.9 years. The figure also shows that there was only one woman engineer who had worked in one company for 5.0-5.9 years (the longest in this survey), whilst there were two men engineers, or $4 \%$ of all men engineers, who had worked in one company for the longest period of time, i.e. 8.0-8.9 years. The comparisons in Figure 1 show that the average working years of women engineers were fewer than those of men in all the categories of same company employment. Therefore, these figures show that women engineers changed their workplaces

Kaewsri, N and Tongthong, T (2011) 'An investigation of women engineers in non-traditional occupations in the Thai construction industry', Australasian Journal of Construction Economics and Building, 11 (2) 1-21 
more often than men engineers. The reasons for the turnover of women and men engineers are shown in Figure 2.

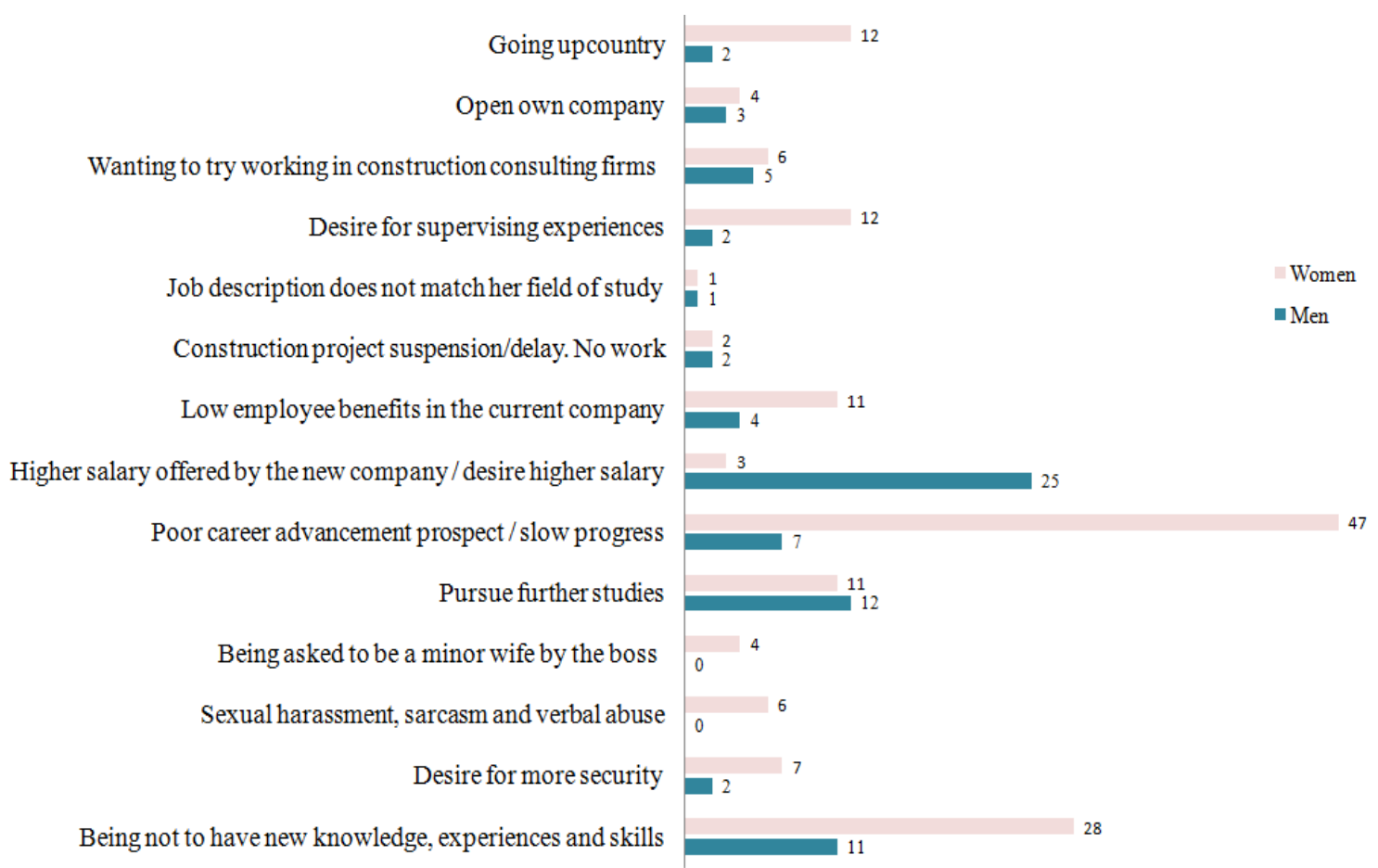

Figure 2 Major reasons for women and men civil engineers leaving contractor companies

As Figure 2 illustrates, the topmost reason for women engineers leaving their jobs was poor career advancement prospects, leading to a feeling of under-achievement. This reason was cited 47 times. The second leading cause of women engineers leaving was the slow work progress linked to the difficulty in acquiring the necessary knowledge, experiences and skills. This reason was given 28 times, The third most important cause of turnover in the careers of women engineers was the desire for experience in supervising a workforce and to go upcountry. This reason was given 12 times. Where men engineers are concerned, the most important reason for leaving their jobs was the desire for better remuneration. This reason was given 25 times. The second most important reason for turnover among men was the desire to pursue higher education. A total of 12 responses were recorded. The third most important cause was slow progress in the acquisition of knowledge, experiences and skills, this accounting for 11 responses. Therefore, it is clear that the foremost reasons for women engineers and men engineers leaving their jobs are different. Men engineers aspired to have better employment whereas women engineers were unhappy with what they perceived as under-achievement in their careers where advancement opportunities were limited and slow to come by.

When reasons for the employment turnover of women and men engineers were investigated, it was noted that women quitted their jobs because of sexual harassment, sarcasm and verbal abuse while men engineers did not face these problems (See Figure 2). In contractor companies, women engineers had to work mainly with men superiors, colleagues and subordinates. In addition, construction site work was hazardous, and being a predominantly male domain, women were more prone to sexual harassment.

Kaewsri, N and Tongthong, T (2011) 'An investigation of women engineers in non-traditional occupations in the Thai construction industry', Australasian Journal of Construction Economics and Building, 11 (2) 1-21 


\section{Conclusions}

Although the number of women civil engineers has been growing, they are still underrepresented in the Thai construction industry (The Council of Engineering in Thailand, 2009). This three-part study presents an analysis of data on the multi-faceted hurdles faced by women engineers in contractor firms. In the first part, work experience of women engineers in the construction industry was viewed from the perspectives of two groups of women engineers, namely those working in contractor companies as well as those from non-contractor companies. Work challenges, problems in non-traditional careers, women's career advancement compared to men's, and career path guidelines provided to women engineers were the issues taken into consideration by the two groups of women engineers. Women engineers working in noncontractor companies seemed to have more opportunities of advancing in their careers and faced fewer problems of working in non-traditional careers than women engineers working in contractor companies. Thus, women engineers working in contractor companies had more limited career opportunities than women engineers working in non-contractor companies.

The second part of this study is concerned with whether women should be civil engineers, and their career progression in the construction industry. The perceptions of three groups of engineers including women and men engineers working in contractor companies, and women working in non-contractor companies were compared. Women and men engineers working in contractor companies shared the view that women should not be civil engineers because they had fewer career opportunities than their male counterparts in contractor companies, whilst women working in non-contractor companies thought otherwise. Further, the perceptions of both women and men engineers were similar with regard to opportunities for career progression for women in the construction industry.

In the third part, the perspectives of both women and men working in contractor companies were taken into account. The employment turnover rates for women engineers in contractor companies were higher than those of their male counterparts in contractor companies. Unlike men engineers who usually left because of their desire for higher salaries, women engineers in contractor companies left mainly because of dissatisfaction with career prospect.

Hence, working in non-contractor companies seems to be a desirable option for women engineers. Unless contractor companies undertake major policy changes regarding women engineers, the latter might shy away from embarking on civil engineering careers in contractor companies. It is hoped that the findings of the current study will bring about such changes so as to encourage women engineers to achieve more in their careers as civil engineers, and to work as professionals on par with men. If the cultural and industry biases in construction organizations can be resolved to meet the needs of the Thai construction industry (Dainty et al., 2000a, b; Khazanet, 1996), more women will remain in the industry, and that will help to avert labour shortages in this sector in the future. Besides, the information from this study can be used by construction and construction-related companies to motivate attract and retain women engineers in the Thai construction industry.

\section{Limitations of the study}

In this study, when collecting information on the average working years of both women and men engineers, the researcher did not take into consideration the type of business they were engaged in; hence the calculation was based on data from men and women engineers who were employed in construction companies at the time of the study. However, since the working years of both men and women engineers were calculated in the same way, they were valid for comparison purposes. Another limitation was that during the pilot study, women engineers in

Kaewsri, N and Tongthong, T (2011) 'An investigation of women engineers in non-traditional occupations in the Thai construction industry', Australasian Journal of Construction Economics and Building, 11 (2) 1-21 
contractor companies had working restrictions while men engineers in contractor companies and women engineers working in non-contractor companies did not. Had data been collected from men engineers working in non-contractor companies, it might have contributed to a more comprehensive view of women engineers' problems in construction companies.

\section{Acknowledgement}

The authors would like to thank the Kasem Bundit University for generously funding this research.

\section{References}

Agapiou, A. (2002) 'Perceptions of Gender Roles and Attitudes toward Work among Male and Female Operatives in the Scottish Construction Industry', Construction Management and Economics, 20 (8), 697-05

Amaratunga, D.R., Haigh, A.L., Shanmugam, M. and Elvitigala, G. (2005) 'Construction Industry and Women: A Review of the Barriers', Research Institute for the Built and Human Environment, Review paper, University of Salford , 559-7, 20 Sep 2008

Angus, R.B. Gundersen, N.A. and Cullinane, T.P. (2000) Planning, Performing, and Controlling Projects: Principles and Applications, Prentice Hall, New Jersey

Arslan, G. and Kivrak, S. (2004) 'The Lower Employment of Women in Turkish Construction Sector', Building and Environment, 39, 1379-87

Bagilhole, B.M., Dainty, A.R.J. and Neale, R.H. (2002) 'A Woman Engineer's Experiences of Working on British Construction Sites', International Journal of Engineering Education, 18 (4), 422-29

Bennett, J.F., Davidson, M.J. and Gale, A.W. (1999) 'Women in Construction: A Comparative Investigation into the Expectations and Experiences of Female and Male Construction Undergraduates and Employees', Women in Management Review, 14 (7), 273-91

Byrne, J., Clarke, L. and Meer, M.V.D. (2005) 'Gender and Ethnic Minority Exclusion from Skilled Occupations in Construction: A Western European Comparison', Construction Management and Economics, 23 (10), 1025-34

Clarke, L. and Gribling, M. (2008) 'Obstacles to Diversity in Construction: The Example of Heathrow Terminal5', Construction Management and Economics, 26 (10), 1055-65

Dainty, A.R.J., Neale, R.H. and Bagilhole, B.M. (1999) 'Women Careers in Large Construction Companies: Expectations Unfulfilled?', Construction Management and Economics, 4 (7), 353-57

Dainty, A.R.J., Neale, R.H. and Bagilhole, B.M. (2000) 'Comparison of Men's and Women's Careers in the U.K. Construction Industry', Journal of Professional Issues in Engineering Education and Practice (ASCE), 126 (3), 110-15

Dainty, A.R.J., Bagilhole, B.M. and Neale, R.H. (2000) 'A Grounded Theory of Women's Career Under-Achievement in Large UK Construction Companies', Construction Management and Economics, 18 (2), 239-50

Dainty, A.R.J., Bagilhole, B.M. and Neale, R.H. (2001) 'Male and Female Perspectives on Equality Measures for the UK Construction Sector', Women in Management Review, 16 (6), 297-04

Dainty, A.R.J., Bagilhole, B.M., Ansari, K.H. and Jackson, J. (2004) 'Creating Equality in the Construction Industry: An Agenda for Change for Women and Ethnic Minorities', Journal of Construction Research, 5 (1), 75-86

Kaewsri, N and Tongthong, T (2011) 'An investigation of women engineers in non-traditional occupations in the Thai construction industry', Australasian Journal of Construction Economics and Building, 11 (2) 1-21 
Dainty, A.R.J. and Edwards, D.J. (2003) 'The UK Building Education Recruitment Crisis: A Call for Action', Construction Management and Economics, 21 (11), 767-75

Dainty, A.R.J. and Lingard, H. (2006) 'Indirect Discrimination in Construction Organizations and the Impact on Women's Career', Journal of Management in Engineering, 22 (3), 108-18

Elvitigala, G., Amaratunga, D. and Haigh, R. (2006) 'The Impact of Culture on Career Development of Women in Construction', Research Institute for the Built and Human Environment, Review paper, The University of Salford, 162-69 11 Jan 2009

English, J., Haupt, T.C. and Smallwood, J.J. (2006) 'Women, Construction and Health and Safety (H\&S): South African and Tanzanian Perspectives', Journal of Engineering, Design and Technology, 4 (1), 18-28

Fielden, S.L, Davison, M.J, Gale, A.W. and Davey, C.L. (2000) 'Women in Construction: the untapped resource', Construction Management and Economics, 18 (1), 113-21

Fielden, S.L., Davison, M.J., Gale, A.W. and Davey, C.L. (2001) 'Women, Equality and Construction', Journal of Management Development, 20 (4), 293-04

French, E. and Strachan, G. (2009) 'Evaluating Equal Employment Opportunity and Its Impact on the Increased Participation of Men and Women in the Transport Industry', Transportation Research Part A, 43 (1), 78-89

Gale, A.W. (1994) 'Women in Non-traditional Occupations: The construction Industry', Women in Management Review, 9 (2), 3-14

Greed, C. and Reeves, D. (2005) 'Mainstreaming equality into strategic spatial policy making: are town planners losing sight of gender?', Construction Management and Economics, 23 (10), 1059-70

Hossain, J.B. and Kusakabe, K. (2005) 'Sex Segregation in Construction Organization in Bangladesh and Thailand', Construction Management and Economics, 23 (6), 609-19

Hossain, J.B. (2007) Women Engineers in Construction Industry: A Comparative Study in Bangladesh and Thailand, Unpublished Dissertation, AIT, Thailand

Khazanet, V.L. (1996) 'Women in Civil Engineering and Science: It's Time for Recognition and Promotion', Journal of Professional Issues in Engineering Education and Practice, 122 (2), 6568

Ling, F.Y.Y. and Poh, Y.P. (2004) 'Encouraging more female quantity surveying graduates to enter the construction industry in Singapore', Women in Management Review, 18 (8), 431-36

Lingard, H. and Lin, F. (2004) 'Career, family and work environment determinants of organizational commitment among women in the Australian construction industry', Construction Management and Economics, 22 (4), 409-20

Lingard, H. and Francis, V. (2005) 'The Decline of the 'Traditional' Family: Work-Life Benefits as a Means of Promoting a Diverse Workforce in the Construction Industry of Australia, Construction Management and Economics, 23 (12), 1045-57

Madikizela, K. and Haupt, T. (2010) 'Influences on Women's Choices of Careers in Construction: A South Africa Study', Australasian Journal of Construction Economics and Building, 10 (1-2), 1-15

Menches, C.L. and Abraham, D.M. (2007) 'Women in Construction-Tapping the Untapping Resource to Meet Future Demands', Journal of Construction Engineering and Management, 133 (9), 701-07 
Neuman, W.L. (1994) Social Research Method: Qualitative and Quantitative Approaches, University of Wisconsin, USA

Ogunlana, S., Rost, U., Robles-Austriaco, L., Kusakabe, K. and Kelkar, G. (1993) Thai Women Construction Workers. Interdisciplinary Studies in Gender and Development in Conjunction with the Structural Engineering and Construction Program, Research report, AIT. Thailand

Parmley, R. O. (2003) Civil Engineer's Illustrated Sourcebook, McGraw-Hill Publishing, Available Online: http:// www.books.google.co.th/ books, Retrieved 25 Jan 2008

Schneider, B. (1976) Staffing Organization, Goodyear Publishing Company, Inc. Santa Monica, California

The Thailand Research Fund, Available Online: http:// www.mua.go.th, Retrieved 26 Feb 2009

Whittock, M. (2002) 'Women's experiences of non-traditional employment: is gender equality in this area a possible?', Construction Management and Economics, 20 (5), 449-56

Yates, J.K. (2001) 'Retention of Non-traditional Engineering and Construction Professionals', Journal of Management in Engineering, 17 (1), 41-48 